\title{
BREXIT W ŚWIETLE WYBRANYCH TEORII (DEZ)INTEGRACJI EUROPEJSKIEJ
}

\author{
BREXIT IN LIGHT OF SELECTED THEORIES \\ OF EUROPEAN (DIS)INTEGRATION
}

\author{
Krzysztof Zuba* $\odot$
}

Ujawniające się w ramach Unii Europejskiej (UE) procesy dezintegracyjne wywołują potrzebę i postulaty stworzenia teorii dezintegracji europejskiej. Obecnie możemy mówić co najwyżej o istnieniu zaczątków takich teorii. W niniejszym opracowaniu podjęto próbę wykazania, że istniejące teorie integracji europejskiej mogą być $\mathrm{z}$ powodzeniem wykorzystane do analizy procesów dezintegracyjnych. Można tego dokonać relatywnie prostym zabiegiem, poprzez potraktowanie ich w sposób „odwrócony”. Innymi słowy, teorie te - tak jak można stosować przy eksplanacji procesów integracji, tak też można zastosować dla wyjaśnienia, dlaczego niektóre państwa nie chcą lub nie mogą uczestniczyć w procesach zbyt daleko idącej integracji europejskiej. W artykule niniejszym, wykorzystując metodę studium przypadku, wskazano na potencjał, jaki posiadają dwie teorie integracji: federalistyczna i międzyrządowa w wyjaśnieniu fenomenu Brexitu. Rozpoczęcie negocjacji o wyjściu Wielkiej Brytanii z UE przedstawia się jako skutek bądź to nieprzystawalności
\end{abstract}

Occurring within the European Union (UE), various disintegration processes create a need and demand for developing a theory of European disintegration. At present it is possible to talk at most about the existence of the beginnings of such theories. This article is an attempt to prove that the existing theories of European integration can be applied successfully in analyses of disintegration processes. This could be achieved by means of a relatively simple procedure, i.e., by dealing with such processes in a "reversed" manner. In other words, if these theories are useful in analysing integration processes, they can also be used to explain why some Member States do not want to or cannot participate in far-reaching European integration processes. Based on the case study method, this article focuses on the United Kingdom. It indicates the potential of the federalist and intergovernmental integration theories for explaining the phenomenon of Brexit. The beginning of negotiations on the United Kingdom's leaving the EU appears to be either

* Uniwersytet Opolski, Wydział Nauk Społecznych. 
i braku akceptacji dla modelu federalistycznego, bądź to jako fiasko promowanego modelu integracji międzyrządowej.

Słowa kluczowe: teoria integracji europejskiej; dezintegracja europejska; Brexit; federalizm; teoria międzyrządowa the consequence of the country's unsuitability and lack of acceptance for the federalist model or the fiasco of the intergovernmental model of integration previously promoted by London.

Keywords: theories of European integration; European disintegration; Brexit; federalism; intergovernmentalism

Rozpoczęcie w marcu 2017 r. negocjacji o opuszczeniu przez Wielką Brytanię Unii Europejskiej (UE) uruchomiło - i to w sposób radykalny - proces, idący pod prąd dotychczasowym tendencjom integracyjnym na kontynencie europejskim. Wszczęcie „procedury rozwodowej”, która najpewniej doprowadzi do formalnego opuszczenia przez Wielką Brytanię UE'1, samo w sobie stanowi jeden z najbardziej ewidentnych przejawów procesów dezintegracji.

Aż do Brexitu Wspólnoty, a następnie UE, konsekwentnie rozszerzały i pogłębiały integrację, niezależnie od pojawiających się okresów jej spowolnienia. Nawet te państwa, które formalnie pozostają poza strukturami europejskimi (Norwegia, Szwajcaria), podlegały silnym tendencjom europeizacji, coraz bardziej wchodząc w obręb wspólnej przestrzeni społeczno-ekonomicznej, a po części również politycznej. Prowadziło to do ukształtowania się przekonania o swoistym determinizmie integracji europejskiej oraz jej bezalternatywności. W wymiarze teoretycznym znalazło to usankcjonowanie i płaszczyznę eksplanacyjną $\mathrm{w}$ ramach teorii funkcjonalistycznej. Była to jedna $\mathrm{z}$ wielu teorii, gdyż proces integracji europejskiej doczekał się niezmiernie rozbudowanego aparatu teoretycznego. Obok „klasycznych” modeli pojawiły się ich nowe interpretacje, a obok ustrukturyzowanych, koherentnych propozycji - szereg koncepcji aspirujących do statusu teorii integracji. Ta swoista inflacja propozycji teoretycznych jest wyraźnym dowodem fenomenu integracji europejskiej, ale implicite również dominacji przekonania o jej nienaruszalnych podstawach.

1 Niektórzy analitycy rozważają scenariusz ponownego referendum zatwierdzającego rezultaty negocjacji. W przypadku jego negatywnego wyniku możliwe byłoby zakwestionowanie samej decyzji o opuszczeniu UE, a co z tym związane przywrócenie stanu członkowskiego. Scenariusz ten należy uznać za mało prawdopodobny. Należy również wziąć pod rozwagę scenariusz, że wyjście z UE nie dokona się w sposób radykalny i całkowity, zaś Wielka Brytania formalnie pozostająca poza strukturami UE, będzie wciąż uczestniczyła w wielu wymiarach integracyjnych. Takie stanowisko w $2016 \mathrm{r}$. sformułowali m.in: Paolo Gentioni, minister spraw zagranicznych Włoch, oraz Günter Oettinger, komisarz ds. gospodarki cyfrowej i społeczeństwa (Gentioni..., 2016; Kroet, 2016). 
Inaczej niż integracja europejska procesy dezintegracji UE doczekały się zaledwie podstawowego zasobu teoretycznego. Wbrew tytułowi takiej propozycji nie dostarcza na przykład artykuł Jana Zielonki (2012). Dzieje się tak niezależnie od tego, że procesy dezintegracyjne w skali europejskiej są przez badaczy nie tylko dostrzegane, ale również poddawane coraz gruntowniejszej analizie (Bideleux, 1996; Rudowski, Zenderowski, 2009; Becker, 2017).

Celem niniejszego opracowania jest wskazanie na potencjał, jaki dla zrozumienia procesów dezintegracyjnych mają teorie integracji europejskiej. Zasadniczo rzecz ujmując, teorie te zostały stworzone na potrzeby analizy, zrozumienia i wyjaśnienia procesów integracyjnych, zachodzących od lat 50. $\mathrm{XX}$ w. na kontynencie europejskim. Część z nich ma również znaczące walory predyktywne i normatywne. Hipotezą leżącą u podstaw niniejszego opracowania jest twierdzenie: „Teorie integracji europejskiej potraktowane w sposób „odwrócony" dostarczają użytecznej siatki teoretycznej na potrzeby analizy procesów dezintegracji europejskiej".

Innymi słowy, za pomocą teorii integracji możemy nie tylko wyjaśniać, dlaczego państwa europejskie zdecydowały się na coraz bardziej pogłębianą kooperację, ale również dlaczego niektóre z nich nie mogą i/lub nie chcą podlegać tym procesom. Na tego typu potencjał jednej z teorii integracji (neofunkcjonalizmu) zwrócili uwagę Philippe C. Schmitter i Zoe Lefkofridi (2015). Inne propozycje bazują na zaadaptowaniu znacznie szerszych ujęć teoretycznych z zakresu stosunków międzynarodowych (Bauböck, 1997; Vollard, 2008).

Aby zweryfikować tę hipotezę, odwołano się do metody studium przypadku. Przyjęcie Wielkiej Brytanii jako przypadku analitycznego nie powinno budzić wątpliwości (Biskup, 2013, s. 13-17). Wspomniano już o Brexicie jako o radykalnym przejawie dezintegracji europejskiej. Ale przykład Wielkiej Brytanie jest uzasadniony niemal całą historią jej integracji ze Wspólnotami/UE. Trudności i otwarte konflikty, które towarzyszyły wzajemnym relacjom, przysporzyły Zjednoczonemu Królestwu etykietki „trudnego partnera”, a nawet „obcego w Europie”, zaś brytyjską ambiwalentną postawę wobec integracji określano mianem „połowicznej separacji” (George, 1990; Wall, 2008; George, 1992). Można z pełną odpowiedzialnością stwierdzić, że Wielka Brytania stanowi wyjątkowe laboratorium pozwalające testować koncepcje z zakresu tak integracji, jak i dezintegracji europejskiej. Problemy, a zwłaszcza dylematy współpracy Londynu z UE, na tle większości pozostałych państw członkowskiej miały wymiar wyjątkowy, często niemal „przerysowany”. Większość z nich jednakże ma charakter uniwersalny, tyle że w innych państwach występują w znacznie mniejszej skali, stąd też nie 
są tak widoczne. To jeszcze bardziej uzasadnia wybór Wielkiej Brytanii jako studium przypadku, gdyż pozwala uwidocznić i uwypuklić pewne uniwersalne procesy związane z (dez)integracją europejską.

Należy również mocno podkreślić, że uogólniających wniosków dotyczących teorii (dez)integracji nie budujemy na jednym przykładzie Wielkiej Brytanii. Stanowiłoby to bowiem błąd egzemplifikacji - wyprowadzania twierdzeń dotyczących całości zjawiska w oparciu o jeden przykład. Przykład Wielkiej Brytanii służy zweryfikowaniu już istniejących teorii, ze wszystkimi konsekwencjami, jakie niesie ze sobą metoda case study, w tym przede wszystkim założeniami, że każdy inny przykład może:

a) potwierdzić niniejsze ustalenia w całości lub w części;

b) sfalsyfikować poczynione tu ustalenia w całości lub w części (Gillham, 2000; Woodside, 2010).

Wspomniana już wielość teorii i parateorii integracji europejskiej uniemożliwia systematyczną weryfikację choćby kilku najważniejszych z nich. Dlatego też w niniejszym artykule ograniczono się do dwóch modeli:

a) teorii federalistycznej,

b) teorii międzyrządowej (intergovernmentalnej).

Ich wybór wynika $\mathrm{z}$ dwóch powodów. Po pierwsze są to teorie wyraziście konkurencyjne, a jednocześnie na swój sposób komplementarne: przyjęcie założeń jednej z nich prowadzi do odrzucenia założeń drugiej. Po drugie są to teorie, które w największym stopniu stały się podstawą doktryny integracyjnej poszczególnych państw (Zuba, 2017a), a to oznacza, że ich założenia były testowane w praktyce politycznej.

Opracowanie składa się z trzech części. W pierwszej omówiono dezintegracyjny potencjał Brexitu. W drugiej analizie poddano teorię federalistyczną jako podstawę eksplanacyjną Brexitu, w trzeciej zaś to samo przetestowano w odniesieniu do teorii międzyrządowej.

\section{BREXIT JAKO PRZEJAW I JAKO CZYNNIK DEZINTEGRACJI}

$\mathrm{W}$ aspekcie dezintegracji Brexit można rozpatrywać z dwóch perspektyw: jako przejaw i jako czynnik dezintegracji.

W pierwszym aspekcie decyzja Brytyjczyków o wycofaniu się z UE stanowi punkt krytyczny skumulowanych i narastających procesów dezintegracyjnych. Analitycy - zgodnie zresztą z teorią historycznego instytucjonalizmu - wskazują 
na brzemienny charakter, jaki niosła z sobą późna akcesja do Wspólnot (WE). Na początku lat 50. XX w., kiedy wykuwały się podstawy wspólnego rynku, WE zostały stworzone jako emanacja woli i interesów państw założycielskiej szóstki, w tym przede wszystkim Francji i Niemiec. To spowodowało, że do końca lat 60 . przyjęły one protekcjonistyczny charakter, $\mathrm{z}$ absurdalnie rozdętym budżetem Wspólnej Polityki Rolnej i restrykcyjnym systemem zewnętrznej polityki celnej (Moravcsik, 1998, s. 277). Dla Wielkiej Brytanii, powiązanej rozbudowanymi relacjami z państwami Wspólnoty Brytyjskiej (Commonwealthu), nadawało to Wspólnotom model rozwojowy, całkowicie sprzeczny z brytyjską koncepcją, doświadczeniem i interesami (Ludlow, 1998, s. 102). Pamiętać należy, że po II wojnie światowej Wielka Brytania była powszechnie postrzegana jako naturalny lider procesów integracyjnych. To zatem, że Londyn nie zdecydował się na współtworzenie Wspólnot, pozbawiło go szans na nadanie im cech korespondujących z jego koncepcjami i interesami (Dell, 1995, s. 222).

U podstaw decyzji o wejściu Wielkiej Brytanii do Wspólnot - podjętej na początku lat 60. (dwa wnioski członkowskie zablokowane przez Francję) - leżały trzy główne argumenty:

- rozpad Imperium spowodował radykalny spadek znaczenia Wielkiej Brytanii, redukując ją de facto z pozycji światowego mocarstwa do pozycji mocarstwa lokalnego (europejskiego);

- członkostwo jest mimo wszystko korzystne ekonomicznie, co sugerował boom gospodarczy EWG w latach 50. i 60. XX w., zwłaszcza w zestawieniu z relatywnie powolnym wzrostem gospodarki brytyjskiej - członkostwo mocno popierały środowiska gospodarcze, w tym wpływowe lobby finansowe londyńskiego City;

- Brytyjczycy w ramach Wspólnot uzyskają przywódczą pozycję, która pozwoli im zmienić niekorzystne dla nich trendy ewolucji Wspólnot.

Dwukrotne weto prezydenta Francji Charlesa de Gaulle’a - w 1963 r. i 1967 r. - umocniły Wielką Brytanię w tych kalkulacjach. Odczytano je jako przejaw obaw Francji przed przejęciem przez Zjednoczone Królestwo przywódczej roli we Wspólnotach oraz nadmiernym wzmocnieniem ekonomicznym i politycznym Londynu.

Założenia co do szybkiego i pozytywnego wpływu integracji na pozycję światową i kondycję brytyjskiej gospodarki okazały się być fałszywe. Wejście Wielkiej Brytanii do W spólnot w 1973 r. nastąpiło w okresie pogłębiającego się kryzysu naftowego, który mocno uderzył we wszystkie państwa Wspólnoty. Obnażyło to naiwność założeń rządów brytyjskich, że klimat ogólnego wzrostu w ramach 
Wspólnot może skompensować brak reform strukturalnych w gospodarce krajowej. Co gorsza, rząd Edwarda Heatha zgodził się na warunki członkostwa, które analitycy oceniają jako najgorsze z możliwych (Wass, 2008, s. 17; Ludlow, 1998, s. 102).

Już na tym początkowym etapie członkostwa okazało się, w jak niewielkim stopniu Brytyjczycy są w stanie przełamać polityczny dyktat tandemu ParyżBerlin. To zadecydowało też o bezpodstawności drugiego założenia - Zjednoczone Królestwo nie było w stanie zapewnić sobie kluczowego wpływu na bieg spraw we WE, przeciwnie - coraz bardziej było izolowane. Wielka Brytania jako państwo członkowskie była źródłem nieustannych napięć i otwartych konfliktów, które ze swej istoty stanowiły czynnik dezintegracyjny. Kwestia europejska stała się jedną z centralnych płaszczyzn podziałów sceny politycznej, a jednocześnie źródłem napięć pomiędzy Londynem a pozostałymi państwami członkowskimi. W okresie rządów Margareth Thatcher (1979-1990) eurosceptycyzm, czyli programowa krytyka pogłębiającej się integracji, zyskał statut agendy państwowej (Gowland, Turner, Wright, 2010, s. 107). Podziały szczególnie mocno ujawniły się w ramach CP w okresie debaty nad traktatem z Maastricht (1992-1993), prowadząc ją na skraj rozłamu. Zażegnanie tego zagrożenia miało raczej charakter „leczenia objawowego” - ich przyczyny, czyli właśnie spór o charakter Wspólnot oraz uczestnictwo w nich Wielkiej Brytanii, powodowały stan immanentnego konfliktu wewnątrzpartyjnego. I choć późniejsze rządy (zwłaszcza laburzystowskie, 1997-2010) usiłowały zmienić wizerunek Wielkiej Brytanii jako „kłopotliwego partnera”, to udało się to jedynie w bardzo ograniczonym stopniu. Konflikt o wsparcie Amerykanów w wojnie w Iraku uwidocznił nowe pole, na którym interesy oraz pryncypia brytyjskiej polityki rozchodziły się z interesami i pryncypiami pozostałych głównych aktorów europejskiej sceny.

Powrót do władzy konserwatystów pod wodzą Davida Camerona w 2010 r. wyznaczył sześcioletni okres konfliktów o przyszłość i kierunki reformy UE. Znamienne, że choć współkoalicjantem Partii Konserwatywnej (Conservative Party, CP) w latach 2010-2015 byli proeuropejscy Liberalni Demokraci, to rząd jeszcze bardziej zaostrzył antyeuropejską retorykę (Daddow, 2015, s. 80). Rosnąca w siłę Partia Niepodległości Zjednoczonego Królestwa (UKIP) stanowiła coraz większe zagrożenie dla CP, zwłaszcza w tzw. okręgach granicznych. UKIP była zasadniczo partią jednej kwestii - skupiając się niemal wyłącznie na krytyce integracji europejskiej. Jej zwycięstwo w wyborach do Parlamentu Europejskiego w 2014 r. stanowiło memento dla CP. I choć wybory parlamentarne 2015 r. nie potwierdziły siły wyborczej UKIP, to stało się tak w dużej mierze 
dzięki przejęciu jej eurosceptycznego programu i elektoratu przez CP. Z perspektywy ponad sześćdziesięciu lat tak trudnych relacji w żadnym razie nie można traktować referendum europejskiego 2016 r. i uruchomienia negocjacji o opuszczeniu UE przez Wielką Brytanię jako zdarzeń przypadkowych. I choć równie fałszywe byłoby mówienie w odniesieniu do Brexitu o jakimś determinizmie, to jednak samo zjawisko narastania wzajemnych napięć i niezgodności pomiędzy Londynem a Brukselą można opisać w kategoriach śnieżnej kuli (Zuba, 2017b, s. 43).

Drugi wskazany aspekt, czyli Brexit jako czynnik dezintegracyjny, wynika z faktu, że perspektywa wyjścia Wielkiej Brytanii z UE znacząco wpływa na ujawnienie się nowych lub wzmożenie już istniejących czynników dezintegracyjnych w całej Unii. Opuszczenie UE przez Zjednoczone Królestwo nominalnie powinno wzmocnić UE, ale analitycy wskazują na szereg zagrożeń, które mogą prowadzić do odwrotnych skutków - osłabienia, a nawet dezintegracji Unii.

Po pierwsze Brexit tworzy precedens, który - na zasadzie domina - może zachęcić kolejnych członków UE do rozważenia podobnego kroku. Dotyczy to zwłaszcza tych państw, które są ambiwalentne wobec pogłębiania współpracy europejskiej, w pierwszej kolejności Danii i Austrii. Scenariusz zwycięstwa sił eurosceptycznych w tych państwach jest jak najbardziej realny. Warto zwrócić uwagę, jak bardzo ożywczy wpływ na antyeuropejskie siły we wszystkich państwach UE miała już sama zapowiedź Brexitu (Chrisafis, 2016). Przeprowadzenie referendum europejskiego w Wielkiej Brytanii pociągnęło za sobą wzrost żądań zorganizowania podobnego plebiscytu w innych państwach. W badaniu Ipsos MORI z przełomu marca i kwietnia 2016 r. aż 58\% Włochów (we Włoszech konstytucja nie przewiduje referendum w kwestii polityki zagranicznej), 55\% Francuzów i 41\% Polaków oczekiwałoby przeprowadzenia takiego głosowania. Co gorsza, znaczny odsetek respondentów (22\% w Polsce, 41\% we Francji, 48\% we Włoszech) deklarował wolę głosowania za wyjściem ich kraju z UE (Ipsos, 2016).

Po drugie w wyniku Brexitu utrwala się dominacja Niemiec w UE, i to niezależnie od woli samych Niemców. Francuzi nie są w stanie samodzielnie równoważyć potencjału ekonomicznego i politycznego RFN. Wielka Brytania wchodziła w taktyczne sojusze z Francją, powodując, że układ sił w ramach UE był bardziej zbalansowany. Jak to ujął Christian Schweiger, Londyn pełnił w takim układzie rolę „silnika manewrującego” (Schweiger, 2007, s. 82 i n.). $\mathrm{Z}$ drugiej strony Brytyjczycy potrafili wchodzić w taktyczne sojusze z Berlinem, aby blokować przerośnięte ambicje Paryża (Möller, 2014, s. 24). 
Warto wspomnieć, że również dla Polski sojusz z Wielką Brytanią jawił się jako alternatywa dla zbyt ścisłych (i postrzeganych jako asymetryczne) relacji z Niemcami. W swym expose z 2016 r. minister spraw zagranicznych Witold Waszczykowski wskazał Zjednoczone Królestwo jako głównego sojusznika Polski w UE (Waszczykowski, 2016, s. 80). Brexit przekreśla te kalkulacje, powodując, że dwa lata później w expose ministra Jacka Czaputowicza Niemcy - wbrew wcześniejszym kalkulacjom rządu Prawa i Sprawiedliwości - powróciły na pozycję strategicznego partnera (Czaputowicz, 2018).

Po trzecie Brexit urealnia wizję budowy Europy różnych prędkości. Przed referendum o opuszczeniu UE rząd brytyjski przygotowywał propozycje, zgodnie z którymi taki model integracji europejskiej stałby się oficjalnym elementem jego polityki w ramach Unii (Hammond, Gentiloni, 2015). Brexit zdezaktualizował ten plan, ale Europa różnych prędkości powróciła w nowym, znacznie bardziej niebezpiecznym kształcie. Pomysł ten został podniesiony przez państwa założycielskiej „szóstki” jako sposób ucieczki do przodu. Przyspieszenie i pogłębienie integracji może się odbyć w gronie zainteresowanych państw, które nie będą się oglądały na „maruderów” (Palmeri, 2016).

Po czwarte wreszcie opuszczenie przez Wielką Brytanię UE może wpłynąć na osłabienie tendencji wolnorynkowych i deregulacyjnych w Europie. To z kolei może stanowić zapowiedź nasilenia się tendencji nacjonalistycznych w gospodarkach państw członkowskich. Warto pamiętać, że to Londyn był siłą napędową reformy Wspólnej Polityki Rolnej, na którą przez dekady szła lwia część budżetu Wspólnot, a następnie UE (Zuba, 2013, s. 109-110.). To również pod wpływem Wielkiej Brytanii wprowadzono Jednolity Akt Europejski, realnie likwidujący bariery pozataryfowe $\mathrm{w}$ handlu w ramach UE. Brak tak silnego ośrodka promującego liberalizację gospodarki europejskiej może wzmocnić tendencje przeciwstawne, a w konsekwencji sprzyjać dezintegracji.

\section{FEDERALIZM}

Twórcy i rzecznicy federalizmu przyjmują, że na określonym poziomie konwergencji społecznej, ekonomicznej i politycznej federalizm staje się najbardziej racjonalną formą zintegrowania różnych podmiotów w ramach jednej organizacji o cechach państwa. Przekształcenie Wspólnot/UE w państwo będzie paralelne ze zniesieniem państwowości podmiotów tworzących federację, choć zachowają one daleką autonomię. Rzecznicy federalizmu uznawali (i to już w latach 50. 
XX w.), że zjednoczona Europa osiągnęła lub w nieodległej przyszłości osiągnie odpowiedni poziom konwergencji, pozwalający na wprowadzenie federacji. Za główny atut rozwiązania federacyjnego uznawano możliwość efektywnego połączenia zróżnicowanych części w jeden organizm, gwarantujący efektywność wspólnej władzy, a przy tym autonomię jej części. Warunkiem wstępnym jest jednakże ukształtowanie europejskiego demos oraz tożsamości narodowej (w sensie obywatelskim). Wspólna władza w ramach federacji europejskiej staje się skutecznym czynnikiem arbitrażowym, ograniczając poziom konfliktów i tendencje odśrodkowe w ramach Unii (na podst.: Rosamond, 2000, s. 23-30; Borkowski, 2007, s. 49-57).

Koncepcja federalizmu legła u podstaw koncepcji budowy wspólnot europejskich, na długo zresztą przed wprowadzeniem ich w życie (Coudenhove-Kalergi, 2005). Budowa Wspólnot - najpierw Europejskiej Wspólnoty Węgla i Stali, a następnie Europejskiej Wspólnoty Energii Atomowej oraz Europejskiej Wspólnoty Gospodarczej odbiegała od założeń teoretyków federalizmu, ale $\mathrm{w}$ żadnym razie nie zrywała $\mathrm{z}$ jego duchem. Zrezygnowano $\mathrm{z}$ amerykańskich doświadczeń - zdecydowano się nie na jeden wielki skok w federację, ale na cząstkowe (integracja sektorowa) i stopniowe dochodzenie do niej. Na tym etapie nie było jednak zasadniczych kontrowersji co do federalistycznego kierunku integracji. Dowodziły tego nie tylko deklaracje „ojców założycieli”, ale również zaprogramowanie ponadnarodowego charakteru struktur europejskich (Moravcsik, 1998, s. 277).

Analiza Brexitu w kontekście teorii federalistycznej odnosi się do dwóch głównych aspektów. Po pierwsze Wielka Brytania od samego początku powojennej integracji europejskiej odrzucała taką wizję rozwoju Wspólnot, a następnie UE. Po drugie, przykład Wielkiej Brytanii w sposób radykalny pokazywał, że poziom jej konwergencji z pozostałymi państwami kontynentalnej Europy nigdy nie osiągnął - wymaganego przez teorię federalistyczną - poziomu pozwalającego na rezygnację z własnej państwowości i wejście w skład państwa federalnego.

Wielka Brytania może się wykazać bardzo bogatymi tradycjami w zakresie rozwijania koncepcji paneuropejskiej federacji (Mayne, Pinder, de V. Roberts, 1990). Za paradoks należy zatem uznać fakt, że po drugiej wojnie światowej stała się najbardziej zaciętym wrogiem tendencji federalistycznych. Wbrew obiegowym, a z gruntu błędnym opiniom zaliczającym w poczet europejskich federalistów Winstona Churchilla zdecydowanie wykluczał on udział Wielkiej Brytanii w tego typu projekcie. Jego słynne wystąpienie w Zurichu z 1946 r., 
w którym nawoływał do budowy Stanów Zjednoczonych Europy, było jedynie ogólnym manifestem, a nie programem działania. Co więcej, Churchill formułował ten manifest $\mathrm{z}$ pozycji lidera światowej potęgi, uznając, że może być to jedyna szansa dla kontynentalnej części Europy Zachodniej na uniknięcie konfliktów zbrojnych (Lukacs, 2002, s. 98). Już w trakcie Kongresu Ruchu Europejskiego z 1948 r. Churchill pokazał zupełnie inną twarz, przyczyniając się do storpedowania wszelkich odważniejszych deklaracji i zamierzeń utrzymanych w duchu federalistycznym (Moon, 1985, s. 25).

Na każdym etapie rozwoju Wspólnot, a następnie UE, Wielka Brytania jednoznacznie sprzeciwiała się budowie federacji. Poparcie dla takich tendencji ujawniało się jedynie na obrzeżach dwóch głównych partii (Partii Konserwatywnej i Partii Pracy) oraz w ramach Partii Liberalno-Demokratycznej, później zaś w Liberalnych Demokratach. Nawet jednak w tej ostatniej partii, uznawanej za najbardziej proeuropejską na brytyjskiej scenie politycznej, federalizm nigdy nie był nurtem wiodącym.

W pełni uprawnione jest stanowisko, że jednym z głównych powodów niewłączenia się Wielkiej Brytanii w proces integracji europejskiej u samych początków budowy Wspólnot był fakt, że ich twórcy nie ukrywali federalistycznego kierunku (Pearce, 1994, s. 66). Konwersja, jaką w kwestii integracji wykazał się rząd Harolda Mackmillana, wynikała z faktu, że federalizm od końca lat 50. utracił swój status dominującego modelu rozwojowego Wspólnot. Brytyjczycy mieli nadzieję, że wejście do Wspólnot pogrzebie tego typu tendencje.

Federalizm pozostał jednak nurtem wpływowym, wyraźnie zyskując na znaczeniu w XXI w. Podobnie jak w przypadku pozostałych „klasycznych” teorii integracji europejskiej, odrodził się w formie neofederalnej (Pinder, 1985-1986, s. 43). Wyraźne przesłanie federalistyczne zawarte zostało w przemówieniu ówczesnego przewodniczącego Komisji Europejskiej Jacques’a Delorsa w Brugii w 1988 r. Odpowiedź brytyjska była zdecydowana - w tym samym miejscu Margaret Thatcher wygłosiła manifest antyfederalistyczny, który w późniejszym czasie stał się manifestem eurosceptyków (Berend, 2010, s. 64). Tendencje federalistyczne odnajdujemy również w zapisach traktatu z Maastricht, zwłaszcza tych wprowadzających unię bankową, unię walutową oraz postulujących stworzenie „coraz ściślejszej unii” (ever closer union). W ocenie premier Thatcher Maastricht z 1992 r. stanowił swoiste „przekroczenie Rubikonu” na drodze do federacji europejskiej (Thatcher, 1995, s. 473, 615). Rozwiązania te były promowane przez Francję i Niemcy, zaś Wielka Brytania usiłowała im przeciwdziałać, nie była jednak w tym skuteczna (Mazzucelli, 1997, s. 66). Analitycy wskazywali 
również na wyraziste tendencje federalistyczne, które towarzyszyły pracom nad traktatem konstytucyjnym. Zwracali przy tym uwagę, że metoda konstytuanty a takie cechy spełniał Konwent w Sprawie przyszłości Europy - stanowi jeden ze sposobów dochodzenia do federacji (Konopacki, 1998, s. 84). I w tym przypadku Wielka Brytania usiłowała sparaliżować ten kierunek ewolucji UE. Rząd brytyjski zapowiedział przeprowadzenie referendum w kwestii konstytucji europejskiej analitycy byli w pełni zgodni co do niewielkich szans na jego pozytywny wynik. Głosowanie zostało zarzucone, gdyż konstytucja europejska (po negatywnych referendach we Francji i w Holandii) przestała być podstawą dalszych prac reformujących Unię. Podkreślić wypada, że odbywało się to w okresie władzy laburzystów, nierzadko błędnie - w opozycji do stanowiska CP - charakteryzowanych jako rzecznicy pogłębionej integracji. Antyfederalistyczne stanowisko uwypuklił Tony Blair m.in. w trakcie uzgadniania kandydatury na nowego przewodniczącego KE w 2004 r. Blair odrzucił wówczas wbrew woli Niemców i Francuzów kandydaturę Guya Verhofstadta z uwagi na jego federalistyczne poglądy (Blair, 2011, s 706).

Teoria federalistyczna wyjaśnia nam również - tyle że w sposób „odwrócony” - dlaczego Wielka Brytania w sposób obiektywny nie mogła pogłębiać integracji, a w końcu zdecydowała się na radykalny krok opuszczenia UE. Otóż wobec wyjątkowości politycznej, narodowej i ekonomicznej Zjednoczone Królestwo nie podlegało - zakładanym w modelu federalistycznym - procesom konwergencji, które stają się warunkiem sine qua non pogłębionej integracji.

Brytyjczycy - inaczej niż działo się to na kontynencie - nigdy nie podzielali tezy o zmierzchu państwa narodowego, a jeśli już, to odnoszono ją jedynie do państw kontynentalnej Europy (Medrano, 2003, s. 259). Takie stanowisko determinowało ich stosunek do wszystkich rozwiązań cząstkowych, które osłabiałyby ich państwo i prowadziły do nadmiernego wzmocnienia instytucji ponadnarodowych. Odbijała się w tym nie tylko ogromna estyma, jaką Brytyjczycy darzyli swoje państwo, ale również realna obawa, że zbyt daleko idące procesy integracyjne spowodują dezintegrację Zjednoczonego Królestwa. Wynikało to z faktu, że głównym czynnikiem spajającym ich państwo była przede wszystkim silna scentralizowana, demokratyczna władza. Przenoszenie uprawnień decyzyjnych z poziomu państwowego na poziom europejski coraz wyraźniej ujawniało, jak niewiele łączy Anglików, Szkotów, Walijczyków czy obywateli Irlandii Północnej.

To, co miało być czynnikiem przełamującym tendencje nacjonalistyczne, to odpowiedni poziom konwergencji. Ten element teorii federalistycznej rozwinięty został w modelu komunikacyjnym. Zwiększenie interakcji pomiędzy państwami, 
a zwłaszcza ich społeczeństwami i indywidualnymi obywatelami miało prowadzić do zmniejszania znaczenia tego co narodowe i państwowe, a zwiększania znaczenia tego co europejskie. Kluczowym wymiarem komunikacji jest świadomość, a zatem jej konwergencja prowadzi do ukształtowania wspólnej tożsamości na bazie tożsamości cząstkowych. Specyfika państwowa i narodowa Zjednoczonego Królestwa zaprzeczała temu paradygmatowi teorii federalistycznej.

Zarówno dominujące wśród brytyjskich elit politycznych (ale w pewnym sensie również w społeczeństwie) nastroje antyfederalistyczne, jak i przekonanie o obiektywnych, nieprzezwyciężalnych ograniczeniach modelu federalistycznego skutkowało działaniami Londynu zmierzającymi do zastopowania tego kierunku rozwojowego Wspólnot/UE. Uwzględnienie części z nich w Traktacie z Lizbony (m.in. wzmocnienie parlamentów, wprowadzenie procedury wyjścia z UE) okazało się niewystarczające. W Wielkiej Brytanii, zwłaszcza w ramach rządzącej od 2010 r. Partii Konserwatywnej, coraz mocniejszą pozycję zdobywała opcja domagająca się zagwarantowania fundamentalnych elementów brytyjskiej państwowości, w tym szczególnie suwerennego statusu Parlamentu. Spełnienie tego postulatu było niemożliwe, gdyż podważał on fundament jedności UE supremację prawa europejskiego.

Referendum z 23 czerwca 2016 r., którego wynik zaskoczył większość analityków, nie może być z tej perspektywy traktowane jako „nieszczęsny przypadek”. Gdyby wynik był pozytywny, to zasadnicze problemy w relacjach brytyjsko-unijnych pozostałyby, generując nową falę konfliktów. Federalizm stanowił z perspektywy brytyjskiej czynnik dezintegracyjny. Londyn nigdy bowiem nie zaakceptował tego kierunku integracji, zaś jego działania, zmierzające do powstrzymania tendencji federalistycznych, okazały się nieskuteczne. Choć rozpoczęcie negocjacji „brexitowych” sprzyja myśleniu ahistorycznemu („to musiało się tak skończyć”), to można je traktować jako radykalną konsekwencję antyfederalistycznego stanowiska Wielkiej Brytanii w zderzeniu z federalistycznymi tendencjami w ramach UE.

\section{TEORIA MIĘDZYRZĄDOWA}

Teoria międzyrządowa w pewnym sensie odrzucała twierdzenia o fenomenie integracji europejskiej, dlatego też nawiązywała do liberalnego modelu stosunków międzynarodowych. Jej fundamentem było założenie, że integracja europejska dokonuje się pod wpływem państw i w interesie państw. Jej rzecznicy 
nie uznawali istnienia żadnego „końcowego” modelu integracji, jednak jako granicę, której nie można przekroczyć w jej progresie, wskazywali suwerenny status państw członkowskich. Wynikało to z przyjętego paradygmatu, że celem integracji jest zaspokojenie potrzeb i umożliwienie osiągnięcia celów przez państwa członkowskie, niezależnie od faktu, że cele te mogą być różne. Cele, które okazują się sprzeczne, znoszą się lub zostają zablokowane. Uwypukleniu ulegają te, wokół których zgromadzi się największa liczba państw, oraz te, co do których można uzyskać określony, akceptowalny poziom konsensusu. Integracja europejska to zatem gra o sumie zerowej, dlatego też winna być realizowana w oparciu o kalkulacje zysków i strat (Rosamond, 2000, s. 130-150; Borkowski, 2013).

Powiązania Brexitu (a ściślej mówiąc całej brytyjskiej polityki europejskiej, której Brexit stanowił zwieńczenie) z modelem intergovernmentalnym można dokonać głównie w dwóch wymiarach. Po pierwsze integracja międzyrządowa stanowiła podwaliny doktryny integracyjnej wszystkich rządów brytyjskich, niezależnie od różnic ujawnianych w stanowiskach CP i LP (Zuba, 2017c, s. 113 i n.). Po drugie przekroczenie pewnego punktu krytycznego integracji, oznaczające odejście od modelu intergovernmentalnego, pociągnęło za sobą kontrakcję Londynu, mającą na celu zminimalizowanie skutków tej ewolucji lub nawet zmianę jej kierunku.

Pryncypia utożsamiane $\mathrm{z}$ teorią międzyrządową leżały u podstaw pojmowania i akceptacji integracji europejskiej przez wszystkie niemal powojenne rządy Wielkiej Brytanii. Jedynie Edwardowi Heathowi przypisuje się odejście od takiej wizji integracji, choć nie sposób przypisać mu federalistycznych poglądów. Ponadto w swych poglądach Heath był raczej odosobniony, nawet w ramach własnego rządu (Turner, 2000, s. 62-65). Suwerenność, choć na Wyspach interpretowana w sposób unikatowy (jej depozytariuszem jest Parlament), pozostaje „świętym Graalem” brytyjskiej polityki. Rzeczywista supremacja prawodawstwa europejskiego (Page, 2004, s. 42), która ten status naruszała, nigdy nie została zaakceptowana przez brytyjskie rządy. Zwłaszcza konserwatyści usiłowali wynikający stąd delikt zlikwidować poprzez dodatkowe prawodawstwo - najpierw krajowe, a następnie europejskie ${ }^{2}$.

2 W trakcie renegocjacji dotyczących warunków członkostwa Wielkiej Brytanii (2015-2016) premier Cameron proponował wzmocnienie roli parlamentów narodowych poprzez wprowadzenie instytucji „czerwonej kartki” - określona liczba parlamentów państw członkowskich uzyskałaby prawo blokowania inicjatyw ustawodawczych Komisji Europejskiej. Propozycja ta została uwzględniona w porozumieniu podpisanym 19 lutego 2016 r. (Walker, Miller, 2016, s. 2). 
Zasadniczo rzecz ujmując, Wielka Brytania nie akceptowała również ponadnarodowego statusu instytucji europejskich. W latach 50. XX w. uznawano, że jest on sprzeczny z brytyjską konstytucją. W późniejszym czasie ponadnarodowe instytucje UE traktowano jako zło konieczne, usiłując pomniejszyć zakres ich wpływu na politykę Zjednoczonego Królestwa. Problem polegał na złożoności WE, a zwłaszcza UE. Od samego początku w ich ramach współgrały pierwiastki supranarodowe i międzynarodowe. Polityka Londynu zawsze zmierzała do zwalczania tych pierwszych, a wzmacniania tych drugich (Jones, 2007, s. 109).

Warto podkreślić, że podjęta na początku lat 60. XX w. decyzja rządu brytyjskiego o złożeniu wniosku akcesyjnego do Wspólnot Europejskich została zdopingowana zmianą europejskiej orientacji Francji. Dojście w 1958 r. do władzy generała de Gaulle’a wyznaczyło nowy etap relacji Francji z Brukselą. Wizja nowego prezydenta Francji bazowała na założeniach współpracy międzyrządowej. Przejawem tych dążeń był kryzys pustego krzesła, zaś ich zwieńczeniem kompromis luksemburski z 1966 r. Brytyjskie rządy, zarówno te tworzone przez Partię Konserwatywną (CP sygnowała pierwszą aplikację z 1961 r.), jak i Partię Pracy (sygnowała drugą aplikację z 1967 r.), podzielały taką wizję i gotowe były zaakceptować członkostwo we Wspólnotach opartych na jej pryncypiach (Yesilada, Wood, 2010, s. 28). Paradoksem było zatem, że to właśnie de Gaulle dwukrotnie zastopował brytyjskie członkostwo we WE, ale - co należy podkreślić - u podstaw tych decyzji nie leżały różnice w postrzeganiu integracji. U podstaw weta leżały obawy Francji związane z przywódczymi ambicjami Londynu we Wspólnotach oraz różnice interesów ekonomicznych (w tym przede wszystkim w kwestii Wspólnej Polityki Rolnej oraz Polityki Połowowej).

Bodaj najbardziej dojrzałym i pełnym manifestem intergovernmentalizmu był program zawarty w stanowisku rządu Margaret Thatcher, zatytułowanym „Przyszłość Europy”, opublikowanym w 1984 r. na łamach „Journal of Common Market Studies”. W dokumencie tym nakreślono model integracji oparty na wolnościach ekonomicznych, ale pozbawiony ponadnarodowych struktur politycznych. Taką wizję uznawano za „powrót do źródeł” integracji, wyraźnie sugerując, że już na początku lat 80 .XX w. integracja na niektórych polach zaszła zbyt daleko (Her Majesty Government, 1984, s. 75-78).

Wynegocjowanie, a następnie wprowadzenie w życie (1987) Jednolitego Aktu Europejskiego (JAE) miało być implementacją tych założeń. Warto zwrócić uwagę na samo nazewnictwo. Margaret Thatcher pragnęła pomniejszyć rangę dokumentu, a może ściślej: nadać mu nie tyle europejski (z czym kojarzyła się 
nazwa „traktat”), ile międzynarodowy charakter. Tak jak deklaracja „Przyszłość Europy" w sferze koncepcyjnej miała być manifestem intergovernmentalizmu, tak JAE miał być kamieniem węgielnym nowego modelu Europy w praktyce (Thatcher, 1996, s. 484, 498; Yesilada, Wood, 2010, s. 42).

Droga od JAE do traktatu z Maastricht oznaczała znaczące odejście od brytyjskiej wizji integracji międzyrządowej, a w ocenie dużej części elit Partii Konserwatywnej - wręcz zerwanie z nią. Proces ratyfikacji traktatu z Maastricht co w Wielkiej Brytanii dokonało się w warunkach bezprecedensowych podziałów w ramach rządzącej wówczas CP - mógł zostać pozytywnie zakończony tylko dlatego, że Londyn wynegocjował sobie system „wyłączeń” (opt-outs). Na tamtym etapie dotyczyły one wejścia do unii walutowej oraz przyjęcia tzw. rozdziału socjalnego. Rząd Johna Majora, który ze strony brytyjskiej traktat negocjował, uznawał, że stanowi to system bezpiecznych i trwałych zabezpieczeń przed tendencjami federalistycznymi, forsowanymi przez Paryż i Berlin (Major, 2000, s. 579).

Działaniem zmierzającym do powrotu integracji na tory intergovernmentalne było popieranie przez Londyn rozszerzeń UE, co najbardziej uwidoczniło się w promowaniu tzw. rozszerzenia wschodniego. Rządy brytyjskie uznawały, że rozszerzenie ograniczy, a nawet zastopuje pogłębianie integracji. Przyjęcie nowych państw, zwłaszcza słabiej rozwiniętych, zwiększało bowiem niespójność Unii. Dawało to również szansę na znalezienie sojuszników w walce z motorami profederalistycznego kierunku rozwoju: Niemcami i Francją. Podobne stanowisko reprezentowały również brytyjskie rządy w kwestii rozszerzenia południowego (o państwa bałkańskie) (HM Government, 2014; Ker-Lindsay, 2017, s. 560). Krytycy nie bez racji wskazywali, że takie stanowisko Wielkiej Brytanii bardziej obliczone jest nie tyle na integrację jako taką, ale przeciwnie zwiększenie czynników dezintegracyjnych w ramach UE. Wyłączenia traktatowe jako sposób utrzymania się w ramach intergovernmentalnego modelu integracji europejskiej okazały się rozwiązaniem bardzo zawodnym. Po pierwsze ujawnił się mechanizm tzw. „eurozapadki”. Polegał on na tym, że każde wyłączenie mogło być przez nowy rząd anulowane, zaś jego przywrócenie stawało się niemożliwe bez zgody pozostałych członków UE. Tak stało się z rozdziałem socjalnym, który został podpisany przez rząd laburzystowski Tony Blaira w 1997 r. Po drugie „wyłączenia” tworzyły swoisty „upośledzony intergovernmentalizm”, z uwagi, że był on jednostronny. Pozostałe państwa członkowskie, zacieśniając i pogłębiając integrację europejską, coraz wyraźniej odrzucały ten model.

Można zatem uznać, że od czasów wejścia w życie traktatu z Maastricht wizja rozwoju UE polegająca na dalszym pogłębianiu integracji (ever closer union) 
i wzmacnianiu instytucji ponadnarodowych, reprezentowana przez państwa założycielskiej „szóstki”, coraz bardziej rozchodziła się z wizją brytyjskich rządów, zwłaszcza konserwatywnych, stojących na stanowisku prymatu państwa w ramach UE (intergovernmentalizm). Konflikt o Europę coraz bardziej dzielił $\mathrm{CP}$, grożąc jej rozłamem. Rząd premiera Camerona był pod nieustanną presją eurosceptycznego skrzydła partii, ponawiającego wnioski o przeprowadzenie referendum w sprawie dalszego członkostwa.

Ostatnim akordem walki o powrót na tory intergovernmentalizmu była próba renegocjacji warunków członkostwa Wielkiej Brytanii (2015-2016). Premier Cameron proponował wzmocnienie roli parlamentów narodowych poprzez wprowadzenie instytucji „czerwonej kartki” - określona liczba parlamentów państw członkowskich uzyskałaby prawo blokowania inicjatyw ustawodawczych Komisji Europejskiej. Przypominało to kompromis luksemburski „w wersji light”. W porozumieniu podpisanym 19 lutego $2016 \mathrm{r}$. znalazł się ten postulat oraz kilka innych - raczej retorycznych - elementów, takich jak demokratyzacja, odbiurokratyzowanie UE czy nadanie jej bardziej innowacyjnego charakteru (Walker, Miller, 2016, CDP-0033, s. 2). Eksperci brytyjscy dość sceptycznie ocenili rzeczywisty wpływ tych uzgodnień na przyszły charakter Unii, a zatem i na realną możliwość zmiany istniejących tendencji rozwojowych w kierunku intergovernmentalnym (Hagemann, Hanretty, Hix, 2016). W sumie zatem owe „ustępstwa” UE wobec Wielkiej Brytanii miały charakter symboliczny, nie zmieniając ani fundamentów Unii, ani jej przyszłych kierunków rozwoju.

\section{KONKLUZJE}

Pogłębiające się zainteresowanie procesami dezintegracyjnymi na kontynencie europejskim należy tłumaczyć natężeniem się symptomów tych procesów w rzeczywistości społeczno-politycznej UE. Niezależnie od tego, czy mają one charakter przejściowy czy zwiastują pojawienie się trwałych trendów, uteoretyzowanie dezintegracji europejskiej wydaje się konieczne nie tylko $\mathrm{z}$ akademickiego punktu widzenia. To z kolei pociąga za sobą konieczność stworzenia siatki pojęciowej i analitycznej, umożliwiającej nie tylko zdefiniowanie i eksplanację, ale również naukową prognostykę zachodzących procesów.

O ile integracja europejska doczekała się nadzwyczaj bogatego zasobu teoretycznego, o tyle w odniesieniu do procesów dezintegracyjnych możemy mówić co najwyżej o nieśmiałych próbach stworzenia wstępnej siatki teoretycznej. 
Zaprezentowane tu podejście do problemu wskazuje jednak, że zbyt pesymistyczne oceny w tym względzie nie do końca są uprawnione. Teorie integracji europejskiej mogą bowiem skutecznie strukturyzować i wyjaśniać również procesy dezintegracyjne.

Wybór teorii federalistycznej i międzyrządowej nie był przypadkowy: są to teorie najbardziej klasyczne, zakorzenione w teorii stosunków międzynarodowych, w dodatku na swój sposób wobec siebie konkurencyjne. Można zatem stwierdzić, że są one najbardziej wygodne i podatne na zabieg „odwracania”. Wspomniano już jednak o analizie Philippe C. Schmittera i Zoe Lefkofridi, dotyczącej teorii neofunkcjonalistycznej - ona również wykazała znaczący potencjał w zakresie teoretyzowania procesów dezintegracyjnych. Wstępna analiza, której wyników tu jednak nie zaprezentowano, sugeruje też przydatność teorii komunikacyjnej do wyjaśniania i strukturyzowania procesów dezintegracji. Brak również - jak dotąd - argumentów czy nawet poszlak wskazujących, że pozostałe teorie i quasi-teorie nie mogą służyć jako podstawa teoretyczna dezintegracji.

Jednocześnie dopiero końcowy efekt negocjacji brexitowych odkryje rzeczywistą skalę oddziaływania, jaką wydarzenia te i zjawisko wywarło na proces tak integracji, jak i dezintegracji europejskiej. Kluczowe będzie, czy Brexit w swojej ostatecznej formule przyjmie kształt „soft” czy „hard”. I choć rząd premier Theresy May skłania się ku drugiej z wersji, to ostatecznie wola polityków i nastawienie opinii publicznej może zostać istotnie zmieniona pod wpływem niekorzystnych wskaźników ekonomicznych.

Przykład Wielkiej Brytanii, jakkolwiek wyjątkowy, pokazuje w sposób najdalej idący wartość tego typu zabiegów „odwracania” teorii integracyjnych. W tym miejscu można jedynie postawić hipotezę (nie weryfikując jej jednakże), że mogą one stanowić przydatne narzędzie również w analizie mniej wyrazistych przypadków.

Dotyczy to w szczególności państw Europy Środkowo-Wschodniej. Dojście do władzy sił eurosceptycznych na Węgrzech, w Polsce, Rumunii i na Słowacji, niesie z sobą nowe wyzwania nie tylko o charakterze politycznym, ale i naukowym. Spowalnianie, a w wielu aspektach negowanie procesów integracji europejskiej staje się trudne do wyjaśnienia w oparciu o istniejące kanony teoretyczne. Jednakże ich „odwrócenie” może rzucić nowe światło zarówno na przyczyny eurosceptycznego dryfu państw Europy Środkowo-Wschodniej, jak i na potencjalne konsekwencje tego procesu - tak dla Europy, jak i dla poszczególnych państw. W tym ostatnim aspekcie należy przypomnieć, co legło u podstaw integracji europejskiej. Nie była to bynajmniej piękna idea jedności, ile bardziej 
strach przed skutkami narastających konfliktów politycznych i ekonomicznych, których skutki zaowocowały w XX wieku dwoma najbardziej morderczymi konfliktami w dziejach świata.

\section{BiBLIOGRAFIA:}

Bauböck, R. (1997). Why stay together? A pluralist approach to secession and federation. Institut für Höhere Studien (IHS), Abt. Politikwissenschaft, 51.

Becker, I. (2017). In the Yugoslav Mirror: The EU Disintegration Crisis. Globalizations, 14(6), 840-850.

Berend, I.T. (2010). Europe Since 1980. Cambridge: Cambridge University Press.

Bideleux, R. (1996). European Integration and Disintegration. W: R. Bideleux, R. Taylor (red), European Integration and Disintegration. East and West, (s. 1-21). London: Routledge.

Biskup, P. (2013). Integracja czy dezintegracja? Przyszłość Unii Europejskiej z perspektywy brytyjskiej. Analiza Natolińska, 5(63).

Blair, T. (2011). Podróż. Katowice: Wydawnictwo Sonia Draga.

Borkowski, P.J. (2007). Polityczne teorie integracji międzynarodowej. Warszawa: Difin.

Borkowski, P.J. (2013). Międzyrządowość w procesie integracji europejskiej. Warszawa: ASPRA-JR. Chrisafis, A. (2016). European Far-right Parties Hail Brexit and Push for own Referendums. The Guardian.

Coudenhove-Kalergi, R.N. (2005). Pan-Europa. Racibórz: Państwowa Wyższa Szkoła Zawodowa w Raciborzu.

Czaputowicz, J. (2018). Informacja ministra spraw zagranicznych o zadaniach polskiej polityki zagranicznej w 2018 roku. W: Sprawozdanie stenograficzne $z$ 60. posiedzenia Sejmu Rzeczypospolitej Polskiej w dniu 21 marca 2018 r. (drugi dzień obrad). Warszawa: Sejm Rzeczypospolitej Polskiej.

Daddow, O. (2015). Interpreting the Outsider Tradition in British European Speeches from Thatcher to Cameron. Journal of Common Market Studies, 53(1), 71-88.

Dell, E. (1995). The Schuman Plan and the British Abdication of Leadership in Europe. Oxford: Oxford University Press.

Gentioni (2016): Britain may change mind on Brexit. Pobrane z: http://www.bbc.co.uk/ programmes/p041825r.

George, S. (1990). An Awkward Partner. Britain in the European Community. Oxford: Oxford University Press.

George, S. (red.). (1992). Britain and the European Community: The Politics of Semi-Detachment. Oxford: Oxford University Press.

Gillham, B. (2000). Case Study Research methods. London: Continuum.

Gowland, D., Turner A., Wright A. (2010). Britain and European Integration Since 1945. On the sidelines. London: Routledge. 
Hagemann S., Hanretty Ch., Hix S. (2016). Introducing Cameron's EU red card will have limited impact. The Guardian.

Hammond, P., Gentiloni, P. (2015). Britain and Italy stand together on EU reform. The Daily Telegraph.

Her Majesty Government (1984). Europe - The Future. Journal of Common Market Studies, 23(1), 73-81.

HM Government (2014). Review of the Balance of Competences between the United Kingdom and the European Union. London: EU Enlargement,.

Ipsos (2016). Brexit poll, May. Pobrane z: www.ipsos-brexit-poll-2016-charts.pdf. Jones, A. (2007). Britain and the European Union. Edinburgh: Edinburgh University Press. Keating, M. (2009). The Independence of Scotland. Self-Government and the Shifting Politics of Union. Oxford: Oxford University Press.

Ker-Lindsay, J. (2017). The United Kingdom and EU enlargement in the Western Balkans: from ardent champion of expansion to Post-Brexit irrelevance. Southeast European and Black Sea Studies, 17(4), 555-569.

Konopacki, S. (1998). Dylematy federalizmu europejskiego. Studia Europejskie, 4, 77-92. Kroet, C. (2016). Günter Oettinger: I would not bet on Brexit. Politico. Pobrane z: http:// www.politico.eu/article/gunter-oettinger-i-would-not-bet-on-brexit/.

Ludlow, P. (1998). Cena późnego akcesu: Wielka Brytania a Wspólnota Europejska 1950-1973. W: J. Kranz, J. Reiter (red.). Drogi do Europy (s. 87-102). Warszawa: Centrum Stosunków Międzynarodowych.

Lukacs, J. (2002). Churchill: Visionary. Statesman. Historian. New Haven: Yale University Press.

Major, J. (2000). The Authobiography. New York: HarperCollins Publishers.

Mayne R., Pinder J., de V. Roberts J.C. (1990). Federal Union: The Pionieers. A History of Federal Union. Basingstoke: Macmillan.

Mazzucelli, C. (1997). France and Germany At Maastricht. Politics and Negotiations to Create the European Union. New York: Garland Publishing, Inc.

Medrano J.D. (2003). Framing Europe. Attitudes to European Integration in Germany, Spain, and the United Kingdom. Princeton: Princeton University Press.

Moravcsik, A. (1998). The Choice for Europe. Social Purpose and State Power from Messina to Maastricht. Ithaca: Cornell University Press.

Moon J. (1985). European Integration in British Politics 1950-1963: A Study of Issue Change. Aldershot: Gower.

Möller, A. (2014). Germany. W: A. Möller, T. Oliver (red.). The United Kingdom and the European Union: What would a "Brexit" mean for the EU and other States around the World (s. 23-26). DGAP Analyse

Page, A. (2004). Balancing Supremacy: EU Membership and Constitution. W: P. Giddings, G. Drewry (red.). Britain in the European Union. Law, Policy and Parliament (s. 37-59). Basingstoke: Houndmills.

Palmeri, T. (2016). Ministers of 'core' Europe plan EU's future, Politico. Pobrane z: http:// www.politico.eu/article/ministers-core-europe-plan-eu-future-rome-meetingfounding-members-integration/. 
Pearce, R. (1994). Attlee's Labour Governments 1945-51. London: Routledge.

Pinder J. (1985-1986). European Community and nation-State: A case for a Neo-federalism? International Affairs, 62, 51-54.

Rosamond, B. (2000). Theories of European Integration. Palgrave: Houndmills.

Rudowski, A. Zenderowski, R. (2009) (red.). Zjawiska i procesy dezintegracji w postzimnowojennej Europie. Warszawa: Wydawnictwo UKSW. Vollard, H. (2008). A Theory of European Disintegration, Fourth Pan European Conference on EU Politics. Latvia: University of Latvia, Riga.

Schmitter, P.C., Lefkofridi Z. (2015). Neo-Functionalism as a Theory of Disintegration, Paper presented on "European Disintegration - A Blind Spot of Integration Theory?", Paris: $22^{\text {nd }}$ CES Conference.

Schweiger, Ch. (2007). Britain, Germany and the Future of the European Union. Basingstoke: Palgrave-Macmillan.

Thatcher, M. (1996). Lata na Downing Street. Wspomnienia z okresu petnienia funkcji premiera rządu Zjednoczonego Królestwa. Gdańsk: Wydawnictwo Gdańskie.

Thatcher, M. (1995). The Path to Power. New York: HarperCollins Publishers.

Turner, J. (2000). The Tories and Europe. Manchester: Manchester University Press.

Walker, N., Miller, V. (2016). Parliamentary sovereignty and EU renegotiation, House of Commons Debate Pack, CDP-0033.

Wall, S. (2008). A Stranger in Europe. Britain and the EU from Thatcher to Blair. Oxford: Oxford University Press.

Wass, D. (2008). Decline to Fall. The Making of British Macro-Economic Policy and the 1976 IMF Crisis. Oxford: Oxford University Press.

Waszczykowski, W. (2016). Informacja ministra spraw zagranicznych o zadaniach polskiej polityki zagranicznej w 2016 roku. W: Sprawozdanie stenograficzne z 10 posiedzenia Sejmu Rzeczypospolitej Polskiej w dniu 29 stycznia 2016 r. (drugi dzień obrad). Warszawa: Sejm Rzeczypospolitej Polskiej.

Woodside, A.G. (2010). Case Study Research: Theory, Methods, Practice. Bingley: Emerald.

Yesilada, B., Wood D. (2010). The Emerging European Union. London: Routledge.

Zielonka, J. (2012). Disintegration Theory. Georgtown Journal of International Affairs, Winter-Spring, 51-59.

Zuba, K. (2013). Dryfujące Wyspy. Europejskie dylematy Brytyjczyków. Warszawa: Wydawnictwo Sejmowe.

Zuba, K. (2017a). (red.). Doktryny integracyjne państw Europejskich. Warszawa: Wydawnictwo Sejmowe.

Zuba, K. (2017b.). Rywalizacja międzypartyjna i wewnątrzpartyjna w kampanii referendum europejskiego w Wielkiej Brytanii z 2016 roku. Politeja. Pismo Wydziału Studiów Międzynarodowych i Politycznych Uniwersytetu Jagiellońskiego, 1(46), 23-44.

Zuba, K. (2017c). Wielka Brytania. W: K. Zuba (red), Doktryny integracyjne państw europejskich (s. 111-128). Warszawa: Wydawnictwo Sejmowe. 